\title{
The effect of serum concentration of leptin in fatteners on their productivity
}

\author{
T. Barowicz ${ }^{1}$, M. Pieszka ${ }^{1}$, M. Pietras ${ }^{1}$ and W. Kędzior ${ }^{2}$ \\ ${ }^{1}$ National Research Institute of Animal Production, \\ Department of Animal Nutrition and Feed Science \\ 32-03 Balice, Poland \\ ${ }^{2}$ University of Economics, Department of Food Science \\ Sienkiewicza 4, 30-033 Kraków, Poland
}

\begin{abstract}
Twenty-four Polish Landrace pigs were fed a standard, complete pelleted diet with free access to water. All of the animals were slaughtered at $108 \mathrm{~kg}$ BW and their blood was sampled. During dissection, samples of M. longissimus dorsi (LD) were taken. Serum leptin concentrations were determined by a radioimmunoassay, and the physicochemical and sensory traits of the meat were assayed. The results were categorized into groups with low $(<3 \mathrm{ng} / \mathrm{ml})$ or high $(>5 \mathrm{ng} / \mathrm{ml})$ leptin concentrations. The serum concentration of leptin had no effect on fattening performance or carcass quality. The animals with a higher leptin concentration showed $1 \%$ better meatiness, as reflected in the higher content of ham. No differences in the physicochemical or sensory characteristics of meat were found.
\end{abstract}

KEY WORDS: leptin , fatteners, growth, carcass quality, meat

\section{INTRODUCTION}

Leptin is a protein hormone secreted mainly by adipose tissue cells. It is believed that leptin is a factor controlling body weight and a link between adipose tissue metabolism and the central nervous system (Campfield et al., 1996). In their studies with 6 breeds of pigs, Berg et al. (2003) showed that serum concentrations of leptin vary and the level of this hormone is related to growth rate and carcass quality.

The aim of this study was to determine the relationship between the serum concentration of leptin and fattening traits, slaughter traits and meat quality of fattening pigs.

\section{MATERIAL AND METHODS}

The experiment involved 24 randomly chosen Polish Landrace fatteners of both sexes. At $70 \mathrm{~kg}$ of body weight the animals were fed in accordance with the Nutrient

\footnotetext{
${ }^{1}$ Corresponding author: e-mail: tbarowic@izoo.krakow.pl
} 
Requirements of Pigs (1993). The pelleted feed contained per $1 \mathrm{~kg}, \%$ : crude protein 15.3 , crude fat 2.1 , lysine 0.82 , methionine and cysteine 0.54 , threonine 0.54 , total Ca 0.82, digestible P 0.30, and MJ ME 12.62. Feed were given twice a day. At the end of the experiment all animals were slaughtered at $108 \mathrm{~kg}$ body weight. Blood was sampled during slaughter and, at dissection of the right half-carcass, a sample of M. longissimus dorsi (LD muscle was taken from the area of the last thoracic and first lumbar vertebrae. Meat samples were analysed for chemical composition (Budsławski and Drabent, 1972), $\mathrm{pH}$ was measured in water homogenates according to Polish Standards (PN-77/A-82058), as well as water holding capacity according to Grau and Hamm (1953), and thermal losses. Meat colour was determined according to the $\mathrm{L}^{*} \mathrm{a} \mathrm{b}^{*}$ system. Sensory analysis of thermally treated meat was also made on a 5-point scale according to Baryłko-Pikielna (1975). Meat tenderness was estimated in the LD muscle using an Instron 5542 equipped with a Warner-Bratzler shear instrument. Leptin was determined in blood serum by radioimmunoassay using the Multi-Species Leptin RIA Kit (Linco Research, Inc., St. Charles, MO). The results were subjected to statistical analysis using Statgraphics Plus 4.0 software.

\section{RESULTS}

Serum concentrations of leptin in the fatteners ranged from 1.38 to $9.13 \mathrm{ng} / \mathrm{ml}$, averaging $4.47 \pm 1.25 \mathrm{ng} / \mathrm{ml}$. Pigs were divided according to serum concentrations of leptin into low or high leptin groups, assuming 3 and $5 \mathrm{ng} / \mathrm{ml}$, respectively as borderline values. There were 9 pigs in both groups. Fatteners in the groups under comparison had the same weight gains and showed similar feed conversion.

Table 1. Fattening results and carcass quality assessment, $n=9$

\begin{tabular}{lccr}
\hline \multirow{2}{*}{ Item } & \multicolumn{2}{c}{ Serum concentration of leptin } & \multirow{2}{*}{ SEM } \\
\cline { 2 - 3 } & $<3 \mathrm{ng} / \mathrm{ml}$ & $>5 \mathrm{ng} / \mathrm{ml}$ & \\
\hline Empty body weight, $\mathrm{kg}$ & 106.17 & 106.50 & 0.42 \\
Mean daily gain, $\mathrm{g}$ & 836 & 834 & 12.82 \\
Feed intake, $\mathrm{kg} / \mathrm{kg}$ & 3.00 & 3.03 & 0.04 \\
Cold carcass weight, kg & 83.87 & 83.08 & 0.39 \\
Cold dressing percentage, \% & 79.01 & 78.00 & 0.42 \\
Meatiness, \% & 56.11 & 57.19 & 0.79 \\
Mean backfat thickness from & & & \\
$\quad 5$ measurements, mm & 21 & 20 & 0.6 \\
Weight of loin, $\mathrm{kg}$ & 6.58 & 6.55 & 0.12 \\
Loin eye area, cm & 53.72 & 53.46 & 0.88 \\
Meat of right ham, $\mathrm{kg}$ & 9.00 & 9.02 & 0.10 \\
Meat content of ham, \% & 72.68 & 73.16 & 1.30 \\
\hline * & & & \\
\hline
\end{tabular}

* standard error of the mean

Carcass quality parameters followed the same pattern. Animals with a higher serum concentration of leptin had $1 \%$ greater meatiness, which was 
reflected in a slightly higher meat content of ham and lower carcass fatness. However, the differences were not statistically significant (Table 1). No differences were found in the physicochemical or sensory traits of meat (Table 2). Only the group of fatteners with a low serum concentration of leptin showed a tendency towards poorer water holding capacity and higher heat losses.

Table 2. Physicochemical and sensory traits of fatteners meat $(n=9)$

\begin{tabular}{|c|c|c|c|}
\hline \multirow{2}{*}{ Item } & \multicolumn{2}{|c|}{ Serum concentration of leptin } & \multirow{2}{*}{ SEM } \\
\hline & $<3 \mathrm{ng} / \mathrm{ml}$ & $>5 \mathrm{ng} / \mathrm{ml}$ & \\
\hline Dry matter, \% & 25.45 & 25.49 & 0.15 \\
\hline Crude protein, $\%$ & 23.64 & 23.27 & 0.20 \\
\hline Crude fat, $\%$ & 1.46 & 1.50 & 0.14 \\
\hline $\mathrm{pH}_{24 \mathrm{~h}}$ & 5.35 & 5.36 & 0.01 \\
\hline Water holding capacity, $\%$ & 28.10 & 24.10 & 1.19 \\
\hline Thermal losses, $\%$ & 41.79 & 40.04 & 0.63 \\
\hline Cutting force, $\mathrm{kg}$ & 5.56 & 5.63 & 0.20 \\
\hline \multicolumn{4}{|l|}{ Colour of meat } \\
\hline $\mathrm{L}^{*}$ & 55.67 & 55.57 & 0.90 \\
\hline$a^{*}$ & 14.35 & 14.03 & 0.26 \\
\hline$b^{*}$ & 9.80 & 9.14 & 0.33 \\
\hline \multicolumn{4}{|l|}{ Sensory traits of meat, pts } \\
\hline juiciness & 4.20 & 4.40 & 0.09 \\
\hline tenderness & 4.30 & 4.43 & 0.10 \\
\hline \multicolumn{4}{|l|}{ Aroma } \\
\hline intensity & 4.90 & 4.78 & 0.05 \\
\hline quality & 4.85 & 4.68 & 0.07 \\
\hline \multicolumn{4}{|l|}{ Palatability } \\
\hline intensity & 4.40 & 4.68 & 0.11 \\
\hline quality & 4.37 & 4.68 & 0.11 \\
\hline
\end{tabular}

\section{DISCUSSION}

Literature on the role of leptin in pigs is scarce. Some authors (Berg et al., 2003) believe that serum concentrations of leptin vary according to pig genotype, although this is not supported by other authors (Maćkowiak et al., 2003). Studies of Cameron et al. (2000) on serum leptin concentration in pigs selected for low and high feed intake suggest that animals with a high appetite were characterized by a higher concentration of this hormone, greater deposition of fat and greater feed intake than pigs from the line selected for low appetite. The same authors also showed that the serum concentration of leptin is correlated more with the amount of deposited fat than with feed intake. In our study, the variability of serum leptin concentration was $22 \%$. Small differences between the experimental pigs in backfat thickness and degree of carcass meatiness could be responsible for 
the lack of a significant effect of serum leptin concentration on fattening traits, slaughter traits and quality of the meat obtained.

\section{CONCLUSIONS}

The serum concentration of leptin was observed to have no effect on fattening results and or on the carcass and meat quality of Polish Landrace pigs slaughtered at $108 \mathrm{~kg}$ body weight.

\section{REFERENCES}

Baryłko-Pikielna N., 1975. An Outline of Sensory Analysis of Food (in Polish). WNT, Warszawa Berg E.P., McFadin E.L., Maddock R.R., Goodwin N., Baas T.J., Keisler D.H., 2003. Serum concentrations of leptin in six genetic lines of swine and relationship with growth and carcass characteristics. J. Anim. Sci. 81, 167-171

Budsławski J., Drabent Z., 1972. Methods of Food Analysis (in Polish). WNT, Warszawa

Cameron N.D., Penman J.C., McCullough E., 2000. Serum leptin concentration in pigs selected for high or low daily food intake. Genet. Res. 75, 209-213

Campfield L.A., Smith F.J., Burn P., 1996. The OB protein (leptin) pathway - a link between adipose tissue mass and central neural networks. Horm. Metab. Res. 28, 619-632

Grau R., Hamm R., 1953. Eine einfache Methode zur Bestimmung der Wasserbindung im Muskel. Naturwissenschaften 40, 29

Maćkowiak P., Nowak K.W., Kaczmarek P., Szydłowski M., Kamyczek M., Eckert R., Różycki M., Świtoński M., 2003. Leptin concentration and hypothalamic leptin binding show a low correlation with the amount of fat and weight gains in pigs. In: Materials of II Symposium of Identification of Gene Polymorphism in Domestic Animals and the Mechanisms of their Influence on Productive Traits. Balice (Poland), p. 45

Nutrient Requirements of Pigs. Nutritive Value of Feedstuffs (in Polish), 1993. The Kielanowski Institute of Animal Physiology and Nutrition (Editor). Jabłonna (Poland)

\section{STRESZCZENIE}

\section{Wpływ poziomu endogennej leptyny w surowicy krwi tuczników na ich produkcyjność}

Doświadczenie przeprowadzono na 24 tucznikach pbz żywionych pełnodawkową, standardową mieszanką granulowaną, przy stałym dostępie do wody. Wszystkie zwierzęta poddano ubojowi, pobrano próbki krwi, zaś podczas dysekcji próbki z mięśnia najdłuższego grzbietu. W próbkach surowicy krwi oznaczano poziom leptyny metodą RIA, zaś w mięsie cechy fizykochemiczne i sensoryczne. Na podstawie uzyskanych wyników, dotyczących zawartości leptyny, tuczniki zaszeregowano do grupy o niskim $(<3 \mathrm{ng} / \mathrm{ml})$ lub wysokim $(>5 \mathrm{ng} / \mathrm{ml})$ poziomie tego hormonu. Nie stwierdzono wpływu poziomu leptyny w surowicy krwi na wyniki tuczu oraz jakość tusz. Osobniki o wyższym poziomie leptyny były o $1 \%$ bardziej mięsne, co przełożyło się na większą zawartość mięsa w szynce. Nie stwierdzono zmian w cechach fizykochemicznych i sensorycznych mięsa. 